\title{
PENGARUH KUALITAS SUMBER DAYA MANUSIA, FASILITAS KERJA DAN PEMANFAATAN TEKNOLOGI INFORMASI TERHADAP PRODUKTIVITAS KERJA PEGAWAI DINAS PERDAGANGAN KOTA TEBING TINGGI
}

\author{
${ }^{1}$ J Najri Habibi, ${ }^{2}$ Nelfida, ${ }^{3}$ M. Alam Warda Ritonga, ${ }^{4}$ Asniwaty, ${ }^{5}$ Supriyono \\ $1,2,3,4,5$ Universitas Islam Sumatera Utara \\ lnajiru.habibi@gmail.com, ${ }^{2}$ nelfida.mm@gmail.com, ${ }^{3}$ alam.warda@gmail.com,asniwaty@gmail.com, \\ supriyono.mm@gmail.com
}

\begin{abstract}
This research discusses about the influences of quality of human resource, work facility and utilization of information technology on employees' work productivity at Trade Office of Tebing Tinggi City. The aim of this research is to analyse influences of quality of human resource, work facility and utilization of information technology both partially and simultaneously on employees' work productivity at the office. This is a quantitative research with total sampling technique. Sample is 83 employees. Results show that each independent variable; quality of human resource, work facility and utilization of information technology, partially influences employees' work productivity positively and significantly. quality of human resource has tcount value 4,487 and level of significance 0.000, work facility has 2,219 and 0.034, and utilization of information technology has 2,246 and 0.032. Simultaneously, quality of human resource, work facility and utilization of information technology have significant and positive influences on employees' work productivity at Trade Office of Tebing Tinggi City with Fcount value 23,863 and level of significance 0.000 .
\end{abstract}

Key words: quality of human resource, work facility, utilization of information technology, work productivity, employee.

\begin{abstract}
ABSTRAK : Penelitian ini membahas tentang bagaimana pengaruh kualitas sumber daya manusia, fasilitas kerja dan pemanfaatan teknologi informasi terhadap produktivitas kerja pegawai Dinas Perdagangan Kota Tebing Tinggi. Penelitian ini bertujuan untuk menguji pengaruh kualitas sumber daya manusia, fasilitas kerja dan pemanfaatan teknologi informasi baik secara parsial maupun simultan terhadap produktivitas kerja pegawai Dinas Perdagangan Kota Tebing Tinggi. Penelitian ini merupakan penelitian kuantitatif dengan teknik penarikan sampel yang digunakan adalah total sampling. Sampel sebanyak 34 orang pegawai. Hasil penelitian menunjukkan bahwa variabel kualitas sumber daya manusia memiliki nilai thitung sebesar 4,487 dan signifikansi 0,000, variabel fasilitas kerja memiliki nilai thitung sebesar 2,219 dan signifikansi 0,034, dan pemanfaatan teknologi informasi memiliki nilai thitung sebesar 2,246 dan signifikansi 0,032. Dengan demikian dapat dikatakan bahwa secara parsial masing-masing dari variabel kualitas sumber daya manusia, fasilitas kerja dan pemanfaatan teknologi informasi berpengaruh positif dan signifikan terhadap produktivitas kerja pegawai. Secara simultan, kualitas sumber daya manusia, fasilitas kerja dan pemanfaatan teknologi informasi tersebut juga berpengaruh positif dan signifikan terhadap produktivitas kerja pegawai Dinas Perdagangan Kota Tebing Tinggi dengan nilai Fhitung sebesar 23,863 dan signifikansi 0,000.
\end{abstract}

Kata Kunci : kualitas sumber daya manusia, fasilitas kerja, pemanfaatan teknologi informasi, produktivitas kerja, pegawai

\section{Pendahuluan}

Sumber daya manusia merupakan tenaga kerja yang dimiliki suatu perusahaan atau instansi untuk mencapai tujuan yang telah ditentukan sebelumnya. Sumber daya manusia merupakan elemen penting dalam suatu organisasi yang harus benar-benar diperhatikan untuk menghasilan produktivitas kerja yang tinggi. Produktivitas kerja sumber daya manusia dapat dipengaruhi oleh fasilitas kerja, 
motivasi kerja dan beban kerja yang ada di instansi.

Fasilitas kerja sangatlah penting bagi organisasi, karena dapat menunjang produktivitas kerja pegawai dalam penyelesaian pekerjaan. Fasilitas kerja merupakan sarana pendukung dalam aktivitas organisasi berbentuk fisik, dan digunakan dalam kegiatan normal organisasi, memiliki jangka waktu kegunaan yang relatif permanen dan memberikan manfaat untuk masa yang akan datang. Penggunaan fasilitas kerja yang efektif akan mampu mempermudah pelaksanaan pekerjaan pegawai, sehingga hasil kerja yang diperoleh akan maksimal. Sebaliknya fasilitas kerja yang tidak tersedia secara efektif akan menghambat pekerjaan pegawai.

Fasilitas kerja sangatlah penting bagi organisasi, karena dapat menunjang produktivitas kerja pegawai dalam penyelesaian pekerjaan. Fasilitas kerja merupakan sarana pendukung dalam aktivitas organisasi berbentuk fisik, dan digunakan dalam kegiatan normal organisasi, memiliki jangka waktu kegunaan yang relatif permanen dan memberikan manfaat untuk masa yang akan datang. Penggunaan fasilitas kerja yang efektif akan mampu mempermudah pelaksanaan pekerjaan pegawai, sehingga hasil kerja yang diperoleh akan maksimal. Sebaliknya fasilitas kerja yang tidak tersedia secara efektif akan menghambat pekerjaan pegawai.

Tuntutan persaingan di berbagai bidang harus dijawab dengan perbaikan dan peningkatan kualitas SDM yang ada. Pola pengaturan dan pengawasan sumber daya manusia harus disesuaikan dengan kondisi yang ada. Steward dalam Polanyi

menyebutkan bahwa sumber daya manusia adalah aktiva organisasi yang paling penting. Juga disebutkan oleh Polanyi (2000) bahwa sumber daya ini mempunyai sifat yang unik dan masalah pengukurannya pun komplek dan tidak mudah diidentifikasi ke pemiliknya, tetapi pengetahuan yang dimiliki sumber daya ini memiliki peranan yang besar dalam meningkatkan nilai dan kelangsungan hidup perusahaan. Jadi pengetahuan yang dimiliki karyawan akan menjadi aset yang berharga bagi perusahaan apabila diciptakan, dipelihara dan ditransformasikan dan dikelola sehingga mempunyai manfaat terhadap perusahaan, jika tidak maka pengetahuan tersebut tidak ada artinya. Sumber daya manusia merupakan salah satu aset yang berpengaruh terhadap penyusunan laporan keuangan.

Oleh karena itu, dibutuhkan Sumber Daya Manusia (SDM) yang kompeten untuk menghasilkan sebuah laporan keuangan yang berkualitas. Begitu juga di perusahaan yang bergerak pada usaha dealer mobil, untuk menghasilkan laporan keuangan yang berkualitas dibutuhkan SDM yang memahami dan kompeten dalam akuntansi keuangan. Pesatnya kemajuan teknologi informasi serta potensi pemanfaatannyasecara luas dapat membuka peluang bagi berbagai pihak untuk mengakses, mengelola, dan mendayagunakan informasi keuangan secara cepat dan akurat. Manfaat lain yang ditawarkan dalam pemanfaatan teknologi informasi adalah kecepatan dalam pemrosesan informasi sehingga laporan keuangan dapat disajikan secara tepat waktu.

Teknologi Informasi (TI) telah berkembang dengan pesat pada saat ini. Teknologi Informasi adalah suatu teknologi yang digunakan untuk mengolah data, termasuk memproses, mendapatkan, menyusun, menyimpan, manipulasi data dalam berbagai cara untuk menghasilkan informasi yang berkualitas, yaitu informasi yang relevan, akurat dan tepat waktu, juga dapat digunakan untuk keperluan pribadi, bisnis, dan pemerintahan yang merupakan informasi yang strategis untuk pengambilan keputusan.

Teknologi informasi ini menggunakan seperangkat komputer untuk mengolah data, sistem jaringan untuk menghubungkan satu komputer dengan komputer lainnya sesuai dengan kebutuhan, dan teknologi telekomunikasi digunakan agar data dapat disebar dan diakses secara global. Menurut Kadir dan Triwahyuni (2003: 2), teknologi informasi adalah seperangkat alat yang membantu anda bekerja dengan informasi dan melakukan tugas yang berhubungan dengan pemprosesan informasi. Hal ini dijelaskan bahwa teknologi informasi merupakan suatu gabungan antara teknologi komputer dan teknologi komunikasi.

Teknologi komputer merupakan seperangkat peralatan yang digunakan untuk mengubah data menjadi suatu informasi yang dapat menjadi bahan dalam pengambilan keputusan. Sedangkan kegunaan utama teknologi informasi secara global adalah membantu dalam pemecahan masalah dengan kreatifitas tinggi dan membuat manusia 
semakin efektif dalam memanfaatkannya. Pemanfaatan Teknologi Informasi (TI) untuk mendukung berbagai kebutuhan dan perkembangan organisasi, individu dan perusahaan tentu akan mendatangkan sesuatu yang positif. Namun perlu diketahui bahwa TI dapat membuat kita menjadi insan yang lebih berarti dengan memanfaatkannya untuk hal yang positif. Manfaat Teknologi Informasi (TI) untuk hal yang positif tentu akan mendapat banyak dukungan dari berbagai kalangan

Berdasarkan hasil observasi yang dilakukan oleh penulis di Dinas Perdagangan Kota Tebing Tinggi, terlihat masih rendahnya produktivitas kerja pegawai. Hal itu terlihat dari indikator sebagai berikut: 1. Kurang optimalnya kualitas kerja pegawai, misalnya kualitas pekerjaan yang dihasilkan kurang sesuai dengan standar mutu yang telah ditetapkan. Contohnya: Pegawai masih melakukan kesalahan dalam bekerja sehingga pekerjaan dilaksanakan secara berulang-ulang, yang berakibat pada pemborosan waktu, tenaga, materi, dan anggaran biaya. 2. Kurang optimalnya kualitas kerja pagawai, misalnya masih adanya pegawai yang menyelesaikan suatu pekerjaan belum sepenuhnya sesuai dengan target yang telah ditetapkan. Munculnya permasalahan rendahnya produktifitas kerja tersebut diduga diakibatkan kurangnya kualitas sumber daya manusia, fasilitas kerja serta pemanfaata teknologi informasi yang tersedia di Dinas Perdagangan Kota Tebing Tinggi.

\subsection{Batasan Masalah}

Permasalahan dalam penelitian ini dibatasi dengan hanya mengkaji tentang produktivitas kerja pegawai yang dipengaruhi oleh faktorfaktor seperti kualitas sumber daya manusia, fasilitas kerjja dan pemanfaatan teknologi informasi pegawai yang secara sendiri-sendiri maupun secara bersama-sama memberikan kontribusi ataupun tidak terhadap produktivitas kerja pegawai Dinas Perdagangan Kota Tebing Tinggi.

\subsection{Rumusan Masalah}

Berdasarkan latar belakang masalah dan identifikasi masalah sebagaimana tersebut di atas, rumusan masalah dalam penelitian ini adalah:

a. Bagaimana pengaruh kualitas sumber daya manusia terhadap produktivitas kerja pegawai Dinas Perdagangan Kota Tebing Tinggi. b. Bagaimana pengaruh fasiltas kerja terhadap produktivitas kerja pegawai Dinas Perdagangan Kota Tebing Tinggi.

c. Bagaimana pengaruh pemanfaatan teknologi informasi terhadap produktivitas kerja pegawai Dinas Perdagangan Kota Tebing Tinggi.

d. Bagaimana pengaruh kualitas sumber daya manusia, fasilitas kerjja dan pemanfaatan teknologi informasi secara bersama-sama terhadap produktivitas kerja pegawai Dinas Perdagangan Kota Tebing Tinggi.

\subsection{Tujuan Penelitian}

Berdasarkan rumusan masalah penelitian sebagaimana diuraikan di atas, maka tujuan yang hendak dicapai dalam penelitian ini yaitu:

1) Untuk menganalisis pengaruh kualitas sumber daya manusia terhadap produktivitas kerja pegawai Dinas Perdagangan Kota Tebing Tinggi.

2) Untuk menganalisis pengaruh fasilitas kerja terhadap produktivitas kerja pegawai Dinas Perdagangan Kota Tebing Tinggi.

3) Untuk menganalisis pengaruh pemanfaatan teknologi informasi terhadap produktivitas kerja pegawai Dinas Perdagangan Kota Tebing Tinggi.

4) Untuk menganalisis secara simultan pengaruh kualitas sumber daya manusia, fasilitas kerjja dan pemanfaatan teknologi informasi terhadap produktivitas kerja pegawai Dinas Perdagangan Kota Tebing Tinggi.

\subsection{Hipotesis}

Hipotesis pada penelitian ini dapat dirumuskan sebagai berikut:

1) Ada pengaruh kualitas sumber daya manusia terhadap produktivitas kerja pegawai Dinas Perdagangan Kota Tebing Tinggi.

2) Ada pengaruh fasilitas kerja terhadap produktivitas kerja pegawai Dinas Perdagangan Kota Tebing Tinggi.

3) Ada pengaruh pemanfaatan teknologi informasi terhadap produktivitas kerja pegawai Dinas Perdagangan Kota Tebing Tinggi.

4) Ada pengaruh kualitas sumber daya manusia, fasilitas kerja dan pemanfaatan teknologi informasi terhadap produktivitas 
kerja pegawai Dinas Perdagangan Kota Tebing Tinggi.

\section{Metode Penelitian}

\subsection{Populasi}

Populasi merupakan objek atau subjek yang beredar pada suatu wilayah dan memenuhi syarat-syarat tertentu berkaitan dengan masalah penelitian. Menurut Sugiyono (2017: 61), populasi adalah wilayah yang terdiri atas

Tabel 1. Kerangka Populasi Berdasarkan Jabatan Thn. 2021

\begin{tabular}{|r|l|c|}
\hline No & \multicolumn{1}{|c|}{ Jabatan } & Jlh Populasi \\
\hline 1 & Kepala Dinas & 1 \\
\hline 2 & Sekretaris & 1 \\
\hline 3 & Kepala Bidang & 1 \\
\hline 4 & Kepala Seksi & 5 \\
\hline 5 & Kepala Sub Bagian & 2 \\
\hline 6 & Kepala UPTD & 3 \\
\hline 7 & KTU & 3 \\
\hline 8 & Bendahara Jumlah & 2 \\
\hline 9 & Staf $\quad 35$ \\
\hline \multicolumn{2}{|c|}{} \\
\hline
\end{tabular}

\subsection{Sampel}

Sumber: Dinas Perdagangan Kota Tebing Tinggi, 2021

Sugiono (2017: 116) berpendapat bahwa sampel adalah bagian dari jumlah dan karakteristik yang dimiliki oleh populasi tersebut. Apa yang dipelajari dari sampel itu, kesimpulan yang dilakukan untuk populasi. Oleh karena itu untuk sampel yang diambil dari populasi harus betul-betul representatif (mewakili). Sampel yang baik, yang kesimpulannya dapat dikenakan pada populasi, adalah sampel yang bersifat representatif atau yang dapat menggambarkan karakteristik populasi.

Teknik Sampling adalah suatu cara yang ditempuh dengan pengambilan sampel yang benar-benar sesuai dengan keseluruhan obyek obyek/subyek yang mempunyai kualitas dan karakteristik tertentu yang ditetapkan oleh peneliti untuk dipelajari dan kemudian ditarik kesimpulannya.

Dalam penelitian ini yang menjadi populasi penelitian adalah seluruh pegawai Dinas Perdagangan Kota Tebing Tinggi yang berjumlah 35 orang dan dapat dijelaskan dengan kerangka populasi sebagai berikut :

Tabel 2. Kerangka Sampel Berdasarkan Jabatan 2021

\begin{tabular}{|r|l|r|r|c|}
\hline No & \multicolumn{1}{|c|}{ Jabatan } & Jlh Populasi & Jlh Sampel & Ket \\
\hline 1 & Kepala Dinas & 1 & - & Tidak diteliti \\
\hline 2 & Sekretaris & 1 & 1 & Diteliti \\
\hline 3 & Kepala Bidang & 1 & 1 & Diteliti \\
\hline 4 & Kepala Seksi & 5 & 5 & Diteliti \\
\hline 5 & Kepala Sub Bagian & 2 & 2 & Diteliti \\
\hline 6 & Kepala UPTD & 3 & 3 & Diteliti \\
\hline 7 & KTU & 2 & 3 & Diteliti \\
\hline 8 & Bendahara & 17 & 2 & Diteliti \\
\hline 9 & Staf Jumlah & $\mathbf{3 5}$ & $\mathbf{3 4}$ & \\
\hline \multicolumn{5}{|r|}{} \\
\hline
\end{tabular}

Sumber: Dinas Perdagangan Kota Tebing Tinggi, 2021

penelitian. Teknik pengambilan sampel dalam penelitian ini adalah total sampling. Total sampling adalah teknik pengambilan sampel dimana jumlah sampel sama dengan populasi, Sugiyono (2017: 34). Alasan mengambil total sampling sesuai dengan pendapat Sugiyono tersebut yang menyatakan bahwa apabila total populasi kurang dari 100 maka seluruh populasi dijadikan sebagai sampel dalam penelitian yang dilakukan.

Dengan demikian dapat disampaikan bahwa sampel dalam penelitian ini adalah seluruh populasi yaitu seluruh pegawai di Dinas Perdagangan Kota Tebing Tinggi sebanyak 34 orang. Sampel ini tidak termasuk Kepala Dinas Perdagangan Kota Tebing Tinggi. 
3. Hasil Dan Pembahasan Hasil Penelitian

\subsection{Uji Validitas Data}

Pengujian validitas instrumen menggunakan Analysis Correlate Bivariate untuk mencari Correlation Coefficient dari Product Moment Pearson dengan SPSS. Kemudian dibandingkan dengan nilai rtable untuk $\alpha=$ 0.05 dengan derajat kebebasan $(\mathrm{dk}=\mathrm{n}-2)$ sehingga didapat rtable. Untuk butir pernyataan dengan nilai koefisien korelasi (rhitung) $>r$ table maka butir pernyataan tersebut dinyatakan valid.

Karena jumlah responden yang digunakan untuk uji validitas sebanyak 34 orang, maka nilai rtabel dapat ditentukan dari: $\mathbf{d k}=\mathbf{n - 2}=$ 34-2 $=32$.

Nilai $\mathrm{r}$ tabel dengan $\mathrm{dk}=32$ adalah 0,339 . Oleh karena itu, item pertanyaan dinyatakan valid jika rhitung $>0,339$.

Table 3. Hasil Uji Validitas Variabel Kualitas Sumber Daya Manusia (X1)

\begin{tabular}{|c|c|c|c|}
\hline Variabel & rhitung & rtabel & Keterangan \\
\hline 1 & 0,913 & 0,339 & Valid \\
\hline 2 & 0,881 & 0,339 & Valid \\
\hline 3 & 0,894 & 0,339 & Valid \\
\hline 4 & 0,939 & 0,339 & Valid \\
\hline 5 & 0,518 & 0,339 & Valid \\
\hline 6 & 0,657 & 0,339 & Valid \\
\hline 7 & 0,657 & 0,339 & Valid \\
\hline 8 & 0,939 & 0,339 & Valid \\
\hline 9 & 0,488 & 0,339 & Valid \\
\hline 10 & 0,440 & 0,339 & \\
\hline
\end{tabular}

Table 4 Hasil Uji Validitas Variabel Fasilitas kerja (X2)

\begin{tabular}{|c|c|c|c|}
\hline Nomor Soal & rhitung & rtabel & Keterangan \\
\hline 1 & 0,690 & 0,339 & Valid \\
\hline 2 & 0,785 & 0,339 & Valid \\
\hline 3 & 0,713 & 0,339 & Valid \\
\hline 4 & 0,664 & 0,339 & Valid \\
\hline 5 & 0,505 & 0,339 & Valid \\
\hline 6 & 0,524 & 0,339 & Valid \\
\hline 7 & 0,731 & 0,339 & Valid \\
\hline 8 & 0,538 & 0,339 & Valid \\
\hline 9 & 0,710 & 0,339 & Valid \\
\hline 10 & 0,785 & 0,339 & \\
\hline
\end{tabular}

Table 5. Hasil Uji Validitas Variabel Pemanfaatan Teknologi Informasi (X3)

\begin{tabular}{|c|c|c|c|}
\hline Nomor Soal & rhitung & rtabel & Keterangan \\
\hline 1 & 0,557 & 0,339 & Valid \\
\hline 2 & 0,616 & 0,339 & Valid \\
\hline 3 & 0,752 & 0,339 & Valid \\
\hline 4 & 0,833 & 0,339 & Valid \\
\hline 5 & 0,620 & 0,339 & Valid \\
\hline 6 & 0,557 & 0,339 & Valid \\
\hline 7 & 0,443 & 0,339 & Valid \\
\hline 8 & 0,828 & 0,339 & \\
\hline
\end{tabular}




\begin{tabular}{|r|c|c|c|}
\hline Nomor Soal & rhitung & rtabel & Keterangan \\
\hline 9 & 0,653 & 0,339 & Valid \\
\hline 10 & 0,616 & 0,339 & Valid \\
\hline
\end{tabular}

Table 6 Hasil Uji Validitas Variabel Produktivitas kerja (Y)

\begin{tabular}{|c|c|c|c|}
\hline Nomor Soal & rhitung & rtabel & Keterangan \\
\hline 1 & 0,524 & 0,339 & Valid \\
\hline 2 & 0,527 & 0,339 & Valid \\
\hline 3 & 0,613 & 0,339 & Valid \\
\hline 4 & 0,524 & 0,339 & Valid \\
\hline 5 & 0,642 & 0,339 & Valid \\
\hline 6 & 0,601 & 0,339 & Valid \\
\hline 7 & 0,673 & 0,339 & Valid \\
\hline 8 & 0,772 & 0,339 & Valid \\
\hline 9 & 0,743 & 0,339 & Valid \\
\hline 10 & 0,816 & 0,339 & \\
\hline
\end{tabular}

Sumber: Data diolah-2021

Tabulasi data variabel dependen dan independen yang terdapat pada tabel 5.6 hingga 5.9 tersebut di atas seluruh pernyataan dalam setiap variabel memiliki nilai Corrected Item Correlation (rhitung) lebih besar dari rtabel. Dengan demikian, dapat dikatakan bahwa setiap butir pernyataan adalah valid sehingga penelitian ini dapat diteruskan dalam pengujian reliabilitas.

\subsection{Uji Reliabilitas Data}

Pada penelitian ini, uji reliabilitas menggunakan metode Cronbach Alpha. Reliabilitas diukur dengan menguji tingkat konsistensi hasil pengukuran jika dilakukan pengukuran ulang. Andal atau tidaknya suatu data dapat dilihat dari koefisien alpha yang dihasilkan, data yang mendekati angka 1 (satu) dapat dikatakan memiliki keandalan tinggi. Nilai koefisien Cronbach Alpha yang mendekati 1 menunjukkan bahwa hasil yang diperolehsemakin konsisten sehingga dikatakan mempunyai reliabilitas yang tinggi. Suatu data dikatakan akurat jika nilai koefisien cronbach alpha minimum adalah 0,60. Uji reliabilitas pada penelitian ini menggunakan program SPSS versi 20.0.

Table 7. Hasil Uji Reabilitas

\begin{tabular}{|r|c|c|c|}
\hline Variable & $\begin{array}{c}\text { Cronbach's } \\
\text { Alpha }\end{array}$ & N of Items & $\begin{array}{c}\text { Reabilitas } \\
\text { Status }\end{array}$ \\
\hline X1 &, 911 & 10 & Reliabel \\
\hline X2 &, 859 & 10 & Reliabel \\
\hline X3 &, 845 & 10 & Reliabel \\
\hline Y &, 839 & 10 & Reliabel \\
\hline
\end{tabular}

Sumber: Data diolah-2021

Hasil uji reliabilitas yang dilakukan terhadap variabel dependen dan independen seperti tertera pada tabel $5.10 \mathrm{di}$ atas, terlihat bahwa nilai Cronbach Alpha seluruh variabel berkisar antara 0 sampai 1 dan lebih cenderung mendekati angka 1. Dengan demikian keseluruhan item dalam instrumen pengukuran dapat kategorikan sangat reliabel.

\subsection{Uji Asumsi Klasik \\ 3.3.1 Uji Normalitas Data}

Pengujian normalitas data bertujuan untuk melihat normal tidaknya sebaran data yang akan dianalisis. Model regresi yang baik adalah distribusi normal atau mendekati normal. Untuk melihat normalitas data ini digunakan pendekatan grafik yaitu Normality Probability Plot. Deteksi normalitas dengan melihat penyebaran data (titik) pada sumbu 
diagonal dari grafik. dasar pengambilan keputusan (Santoso, 2004: 214), adalah:

a. Jika data menyebar disekitar garis diagonal dan mengikuti arah garis diagonal, maka model regresi memenuhi asumsi normalitas.

b. Jika data menyebar jauh dari garis diagonal dan atau tidak mengikuti arah garis diagonal, maka model regresi tidak memenuhi asumsi normalitas.

Pada output SPSS bagian normal P-P Plot of Regresion Standardized Residual, dapat dijelaskan bahwa data-data (titik-titik) cenderung lurus mengikuti garis diagonal sehingga data dalam penelitian ini cenderung berdistribusi normal, seperti terlihat pada gambar di bawah ini.

\subsubsection{Uji Multikolinearitas}

Pengujian multikolinearitas dilakukan untuk melihat apakah pada model regresi ditemukan adanya korelasi antara variabel bebas. Jika terjadi korelasi, maka dinamakan terdapat problem multikolinearitas. Cara mendeteksinya adalah dengan melihat nilai Variance Inflation Factor (VIF). Menurut Santoso (2014: 203), pada umumnya jika VIF lebih besar dari 5, maka variabel bebas tersebut mempunyai persoalan multikolinearitas dengan variabel bebas lainnya. Pada output SPSS bagian Coefficient, semua angka VIF berada di bawah 5, hal ini menunjukan tidak terjadi multikolinearitas, seperti dapat dilihat pada tabel di bawah ini.

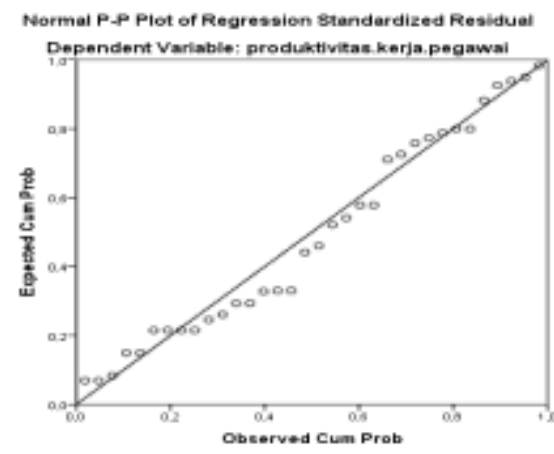

Gambar 5.1. Normalitas Data

Tabel 8 Uji Multikolinearitas

Coefficients $^{\mathbf{a}}$

\begin{tabular}{|l|l|r|r|}
\hline \multicolumn{2}{|l|}{ Model } & \multicolumn{2}{|c|}{ Collinearity Statistics } \\
\cline { 3 - 4 } \multicolumn{2}{l|}{} & Tolerance & \multicolumn{1}{c|}{ VIF } \\
\hline \multirow{4}{*}{1} & Constant) & & \\
\cline { 2 - 4 } & kualitas.S.D.M &, 676 & 1,480 \\
\cline { 2 - 4 } & fasilitas.keria &, 804 & 1.243 \\
\cline { 2 - 4 } & pemanfaatan.T.I &, 758 & 1,320 \\
\hline
\end{tabular}

a. Dependent Variable: produktivitas.kerja.pegawai Sumber: Out Put SPSS. Data Diolah-2021

\subsubsection{Uji Heteroskedastisitas}

Pengujian heteroskedastisitas bertujuan untuk melihat apakah dalam sebuah model regresi terjadi ketidaksamaan varians dari residual yang merupakan suatu pengamatan ke pengamatan yang lainnya. Jika varians dari residual yang merupakan suatu pengamatan ke pengamatan yang lain bernilai tetap, maka hasil data disebut homoskedastisitas dan jika varians berbeda atau bernilai tidak tetap maka disebut heteroskedastisitas. Model regresi yang baik adalah model yang bernilai tetap atau homoskedastisitas atau tidak terjadi heteroskedastisitas.
Deteksi heteroskedastisitas dilakukan dengan cara melihat ada tidaknya pola tertentu pada data yang diolah. Menurut Santoso (2014: 208), dasar pengambilan keputusannya adalah:

a. Jika pola tertentu seperti titik-titik yang ada membentuk suatu pola tertentu yang teratur, maka terdapat situasi heteroskedastisitas.

b. Jika tidak ada pola yang jelas, serta titiktitik menyebar di atas dan di bawah angka nol pada sumbu Y, maka tidak terjadi heteroskedastisitas. Pada output SPSS dibagian Scatrerplot, terlihat titk-titik menyebar secara acak, tidak membentuk sebuah pola tertentu yang jelas, serta 
tersebar baik di atas maupun di bawah angka nol pada sumbu Y. Hal ini berarti tidak terjadi heterskedastisitas pada model regresi, sehingga model regresi layak dipakai. Pola Scatterplot dapat dilihat pada gambar di bawah ini.

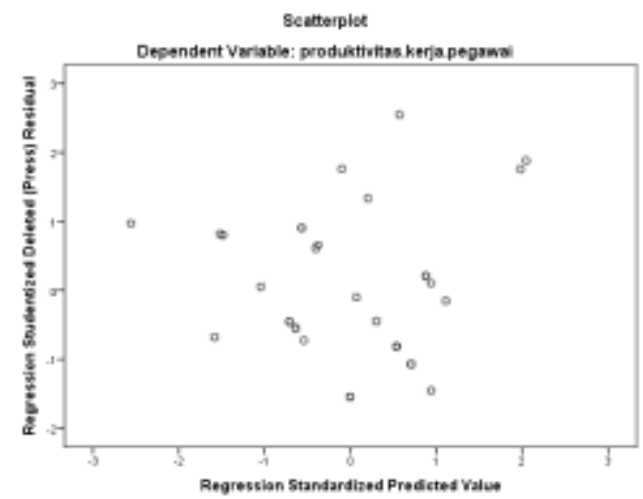

Gambar 5.2. Uji Heteroskedastitas

Tabel 9 Hasil Uji Statistik Koefisien Regresi

Coefficients $^{\mathbf{a}}$

\begin{tabular}{|c|c|c|c|c|c|c|}
\hline \multirow{2}{*}{\multicolumn{2}{|c|}{ Model }} & \multicolumn{2}{|c|}{$\begin{array}{l}\text { Unstandardized } \\
\text { Coefficients }\end{array}$} & \multirow{2}{*}{$\begin{array}{r}\text { Standardized } \\
\text { Coefficients } \\
\text { Beta }\end{array}$} & \multirow[t]{2}{*}{$\mathrm{t}$} & \multirow[t]{2}{*}{ Sig. } \\
\hline & & $\mathrm{B}$ & Std. Error & & & \\
\hline \multirow{4}{*}{1} & (Constant) & 4,830 & 5,717 & & 845 & 405 \\
\hline & kualitas.S.D.M & .400 & 089 & 542 & 4.487 & .000 \\
\hline & fasilitas.keria & 232 & .105 & 246 & 2.219 & .034 \\
\hline & pemanfaatan.T.I & .302 & .134 & .256 & 2.246 & .032 \\
\hline
\end{tabular}

a. Dependent Variable: produktivitas.kerja.pegawai

Dari tabel 9 di atas dapat dibuat persamaan regresi sebagai berikut:

$$
\begin{gathered}
\mathrm{Y}=5,717+0,400 \times 1+0,232 \times 2+0,302 X 3 \\
+\varepsilon .
\end{gathered}
$$

Dari persamaan tersebut dijelaskan bahwa koefesien X1 (Kualitas Sumber Daya Manusia) mempunyai nilai positif yaitu 0,400 . Hal ini menunjukan bahwa variabel Kualitas Sumber Daya Manusia mempunyai pengaruh positif terhadap variabel Produktivitas kerja Pegawai. Koefesien X2 (Fasilitas kerja) memiliki nilai positif yaitu 0,232. Hal ini menunjukan bahwa variabel Fasilitas kerja mempunyai pengaruh positif terhadap variabel

\section{Evaluasi Data \\ 4.1 Pengujian Hipotesis}

Dalam evaluasi data ini penulis akan melakukan pengujian hipotesis, baik secara partial ataupun secara simultan. Selanjutnya untuk mempermudah dalam evaluasi data ini, maka penulis mencari niali-nilai yang dibutuhkan dengan menggunakan perangkat lunak komputer yaitu program SPSS V.20.00 for windows dengan hasil data sebagai berikut:

\begin{tabular}{|c|c|c|c|c|c|c|}
\hline \multicolumn{7}{|c|}{ ANOVAa $^{\mathbf{a}}$} \\
\hline \multicolumn{2}{|c|}{ Model } & Sum of & $\mathrm{df}$ & Mean Square & $\mathrm{F}$ & Sig. \\
\hline \multirow{3}{*}{1} & Regression & 32,416 & 3 & 10,805 & 23,863 &, 000 \\
\hline & Residual & 13,584 & 30 & ,453 & & \\
\hline & Total & 46,000 & 33 & & & \\
\hline
\end{tabular}

Tabel 10 Hasil Uji Statistik Secara Simultan

a. Dependent Variable: produktivitas.kerja.pegawai

b. Predictors: (Constant), pemanfaatan.T.I, fasilitas.kerja, kualitas.S.D.M

Sumber: Out Put SPSS Data Diolah-2021 
Dari tabel 10 di atas dapat diketahui denngan jelas bahwa nilai Fhitung adalah 23,863 dan nilai signifikansi 0,000. Diketahui nilai Ftabel dengan tingkat kepercayaan 95\% $(\alpha: 0,05)$ adalah 2.920. Oleh karena itu nilai Fhitung> Ftabel $\left(23,863>2,920\right.$ maka $\mathrm{Ho}_{\mathrm{o}}$ ditolak dan menerima hipotesis dalam penelitian ini yaitu bahwa Kualitas Sumber Daya Manusia,, Fasilitas kerja, dan Pemanfaatan Teknologi Informasi berpengaruh positif dan signifikan terhadap Produktivitas kerja Pegawai di Dinas Perdagangan Kota Tebing Tinggi.

\subsection{Pengujian Secara Parsial (Uji t)}

Tabel 11 Hasil Uji Parsial Variabel X Terhadap Y

Coefficients ${ }^{\mathbf{a}}$

\begin{tabular}{|l|r|r|r|r|r|}
\hline \multirow{2}{*}{$\begin{array}{l}\text { Model } \\
\text { - }\end{array}$} & \multicolumn{2}{|c|}{$\begin{array}{c}\text { Unstandardized } \\
\text { Coefficients }\end{array}$} & $\begin{array}{c}\text { Standardized } \\
\text { Coefficients }\end{array}$ & \multirow{2}{*}{ t } & \multirow{2}{*}{ Sig. } \\
\cline { 2 - 5 } & \multicolumn{1}{|c|}{ B } & Std. Error & Beta & & \\
\hline 1. & 4,830 & 5,717 & &, 845 &, 405 \\
\hline &, 400 &, 089 &, 542 & 4,487 &, 000 \\
\hline
\end{tabular}

\subsection{Pengaruh $X 1$ terhadap $Y$}

Secara parsial pengaruh Kualitas Sumber Daya Manusia(X1) terhadap Produktivitas kerja Pegawai (Y) dapat diketahui dengan memperhatikan data pada tabel 5.14 di atas. Berdasarkan tabel tersebut diperoleh nilai thitung sebesar 4,487 dan nilai signifikansi 0,000 . Sedangkan nilai ttabel pada tingkat kepercayaan 95\% $(\alpha: 0,05)$ adalah 2,042. Oleh karena itu nilai thitung $>$ ttabel $(4,487>2,042)$ maka Ho ditolak dan menerima hipotesis dalam penelitian ini yaitu variabel Kualitas Sumber Daya Manusia berpengaruh positif terhadap Produktivitas kerja Pegawai di Dinas Perdagangan Kota Tebing Tinggi.

\subsection{Pengaruh $X 2$ terhadap $Y$}

Secara parsial pengaruh Fasilitas kerja (X2) terhadap Produktivitas kerja Pegawai (Y) dapat dilihat pada tebel 5.14 di atas. Berdasarkan tabel tersebut diperoleh nilai thitung sebesar 2,219 dan nilai signifikansi 0,034. Sedangkan nilai ttabel pada tingkat kepercayaan 95\% ( $\alpha$ : $0,05)$ adalah 2,042. Oleh karena itu nilai thitung > ttabel $(2,219>2,042)$ maka $\mathrm{Ho}_{\mathrm{O}}$ ditolak dan menerima hipotesis dalam penelitian ini yaitu Fasilitas kerja berpengaruh positif terhadap Produktivitas kerja Pegawai di Dinas Perdagangan Kota Tebing Tinggi.

\subsection{Pengaruh $X 3$ terhadap $Y$}

Untuk mengetahui secara parsial pengaruh pemanfaatan teknologi informasi (X3) terhadap Produktivitas kerja Pegawai (Y) dapat dilihat pada tabel 5.14 di atas. Berdasarkan tabel tersebut diperoleh nilai thitung sebesar 2,246 dan nilai signifikansi 0,032 . Sedangkan nilai ttabel pada tingkat kepercayaan 95\% ( $\alpha: 0,05)$ adalah 2,042. Oleh karena itu nilai thitung > ttabel (2,246> 2,042) maka $\mathrm{Ho}_{\mathrm{o}}$ ditolak dan menerima hipotesis dalam penelitian ini yaitu variabel Pemanfaatan Teknologi Informasi berpengaruh positif terhadap Produktivitas kerja Pegawai di Dinas Perdagangan Kota Tebing Tinggi.

\subsection{Uji Koefisien Determinasi $\left(\mathbf{R}^{2}\right)$}

Uji determinan digunakan untuk mengetahui seberapa besar pengaruh variabel independent terhadap variabel dependent. Untuk melihat hasil uji determinan maka dapat diketahui nilai $\mathrm{R}$ Square atau koefesien determinasi dapat dilihat di bawah ini. 
Tabel 12 Model Summary

Model Summaryb

\begin{tabular}{|l|r|r|r|r|r|r|}
\hline Model & $\mathrm{R}$ & R Square & \multicolumn{1}{|c|}{$\begin{array}{c}\text { Adjusted R } \\
\text { Square }\end{array}$} & $\begin{array}{l}\text { Std. Error of } \\
\text { the Estimate }\end{array}$ & \multicolumn{2}{|c|}{ Change Statistics } \\
\cline { 6 - 7 } & & &, 675 &, 67291 & \multicolumn{1}{c|}{ R Square } & F Change \\
\hline 1 &, $839 \mathrm{a}$ &, 705 & & & & 23,863 \\
& & & & & & \\
\hline
\end{tabular}

a. Predictors: (Constant), pemanfaatan.T.I, fasilitas.kerja, kualitas.S.D.M

b. Dependent Variable: produktivitas.kerja.pegawai

Pada tabel di atas dapat diketahui bahwa Nilai R Square adalah 0,705. Hal ini menunjukan bahwa $70,50 \%$ variabel Produktivitas kerja Pegawai di Dinas Perdagangan Kota Tebing Tinggi dapat dijelaskan oleh variabel Kualitas Sumber Daya Manusia, Fasilitas kerja dan Pemanfaatan Teknologi Informasi sedangkan sisanya sebesar $29,50 \%$ tidak dilakukan penelitian.

\section{Kesimpulan}

Dari hasil uji yang dilakukan dapat disimpulkan bahwa:

1) Variabel Kualitas Sumber Daya Manusia memiliki nilai thitung sebesar 4,487 dan ignifikansi 0,000. Variabel Fasilitas Kerja memiliki nilai thitung sebesar 2,219 dan signifikansi 0,034 dan variabel Pemanfaatan Teknologi Informasi memiliki nilai thitung sebesar 2,246 dan signifikansi 0,032. Dengan demikian variabel Kualitas Sumber Daya Manusia, Fasilitas kerja dan Pemanfaatan Teknologi Informasi secara parsial atau sendiri-sendiri berpengaruh positif dan signifikan terhadap Produktivitas kerja Pegawai di Dinas Perdagangan Kota Tebing Tinggi.

2) Pengujian yang dilakukan terhadap variabel Kualitas Sumber Daya Manusia, Fasilitas kerja dan Pemanfaatan Teknologi Informasi secara bersama-sama atau simultan berpengaruh positif dan signifikan terhadap Produktivitas kerja Pegawai di Dinas Perdagangan Kota Tebing Tinggi dengan nilai sebesar 23,863 dan signifikansi level 0,000 .

3) Nilai $R$ Square adalah 0,705. Hal ini menunjukan bahwa $70,50 \%$ variabel Produktivitas kerja Pegawai di Dinas Perdagangan Kota Tebing Tinggi dapat dijelaskan oleh variabel Kualitas Sumber Daya Manusia, Fasilitas kerja dan Pemanfaatan Teknologi Informasi sedangkan sisanya sebesar $29,50 \%$ tidak dilakukan penelitian.

\section{DAFTAR PUSTAKA}

Allanita dan Agung Suryawan. 2014. Pengaruh Kecanggihan Teknologi Informasi, Partisipasai Manajemen dan Kemampuan Teknik Pemakaian Sistem Informasi Akuntansi Pada Kinerja Individu. E- Journal Akuntansi Universitas Udayana6.1 (2014) ; 33 - 45.

Dahlius, Apri \& Ibrahim, Mariaty. 2016. Pengaruh Fasilitas Kerja Terhadap Kepuasan Kerja Karyawan pada PT. Bank Riaukepri Cabang Teluk Kuantan Kabupaten Kuantan Singingi. JOM FISIP. Vol. 3 No. 2, Oktober 2016. Hal. 1-13.

Danang, Sunyoto. 2013. Metodologi Penelitian Akuntansi. Bandung: PT. Refika Aditama Anggota IKAPI.

Danim, Sudarwan. 2012. Profesi Kependidikan Manajemen. Bandung : Alfabeta.

Diana, H. 2018. Hubungan Kompensasi dengan Kinerja Karyawan di VICO Indonesia Company Muara Badak Kalimantan Timur. Jurnal Aplikasi Manajemen, 7 (2), 434-440.

Djojowirono. 2005. Manajemen Edisi Keempat, Yogyakarta; Biro Penerbit KMTS FE. UGM

Gardjito, Aldo Herlambang, dkk. 2015. Pengaruh Motivasi Kerja Dan Lingkungan Kerja Terhadap Kinerja Karyawan (Studi pada Karyawan Bagian Produksi PT. Karmand Mitra Andalan Surabaya). Jurnal Administrasi Bisnis (JAB), Vol. 13 No. 1 Agustus 2014|.

Hasibuan, Malayu S.P. 2012. Manajemen

Sumber daya Manusia, Edisi Tiga.

Jakarta : Bumi Akasara.

Hasibuan, S.P Malayu. 2005. Manajemen Sumber Daya Manusia. Jakarta: Bumi Aksara.

Husnan. 2002. Dasar-dasar Manajemen Keuangan. Yogyakarta; UPP YMP YKPN. 
Hutapea dan Nurianna. 2016. Kompetensi Plus. Jakarta : Gramedia Utama. Jogiyanto dan Abdillah, W. 2010. Partial Least Square (PLS) Alternatif SEM Dalam penelitian Bisnis. Yogyakarta : Andi.

Kadir, A. 2013. Manajemen Sumber Daya Manusia Untuk Bisnis Yang Kompetitif. Yogyakarta : Gajahmada University Pers.

Kadir, Abdul dan Triwahyuni, Terra. 2003. Pengendalian Teknologi Informasi. Yogjakarta: Andi.

Komariah. 2018. Pengaruh Fasilitas Kerja terhadap Produktivitas Kerja Pegawai di Dinas Pengendalian Penduduk Keluarga Berencana, Pemberdayaan Perempuan dan Perlindungan Anak Kabupaten Ciamis. Dinamika: Jurnal Ilmiah Ilmu Administrasi Negara, Vol 5, No 3 (2018).

Lantip, Prasojo Diat dan Rianto. 2011. Teknologi Informasi Pendidikan. Yogyakarta : Grava Media.

Lupiyaodi. 2006. Manajemen Pemasaran Jasa.Edisi Kedua. Jakarta: Salemba Empat.

Mathis, L.R dan Jackson, H.J. 2001.

Manajemen Sumber Daya Manusia.

Jakarta: Salemba Empat.

Matindas, R. 2012. Manajemen Sumber Daya Manusia: Lewat Konsep AKU (Ambisi, Karyawan dan Usaha). Jakarta : Pustaka Utama Grafiti.

Mukhammad Hilmi Muzakki, Heru Susilo, Saiful Rahman Yuniarti. 2016.

Pengaruh Penggunaan Teknologi Informasi Terhadap Kinerja Karyawan (Studi Pada Karyawan PT. TELKOM Pusat Divisi Regional V Surabaya). Jurnal Administrasi Bisnis (JAB),|Vol. 39 No.2 Oktober 2016, 169-175.

Mulyana, Deddy. 2010. Ilmu Komunikasi

Suatu Pengantar. Bandung : Remaja

Rosdakarya.

Mulyanto, Agus. 2016. Sistem Informasi Konsep dan Aplikasi. Yogyakarta : Pustaka Pelajar

Munir. 2017. Kurikulum Berbasis Teknologi Informasi dan Komunikasi. Bandumg : Alfabeta.

Muntianah, Siti Tutik, dkk. 2012. Pengaruh Minat Prilaku terhadap Actual Use Teknologi Informasi Dengan Pendekatan Technology Acceptance Model (TAM): Studi Kasus pada Kegiatan Belajar Mahasiswa Fakultas Administrasi
Universitas Brawijaya Malang. Profit Jurnal 6(1).

Mustafa. 2010. Manajemen Keuangan.

Yogyakarta : Andi Offset.

Nasution, MN. 2001. Manajemen Mutu Terpadu. Jakarta: Gahalia Indonesia. Ndraha, Taliziduhu. 2012. Kybernologi (Ilmu Pemerintahan Baru) Jilid 1-2. Jakarta : Rineka Cipta. 